\title{
Inhibitory effect of ethanol extract of Nannochloropsis oceanica on lipopolysaccharide-induced neuroinflammation, oxidative stress, amyloidogenesis and memory impairment
}

\author{
Ji Yeon Choi ${ }^{1}$, Chul Ju Hwang ${ }^{1}$, Hee Pom Lee ${ }^{1}$, Hee Sik Kim² ${ }^{2}$ Sang-Bae Han ${ }^{1}$ and \\ Jin Tae Hong ${ }^{1}$ \\ ${ }^{1}$ College of Pharmacy and Medical Research Center, Chungbuk National University, Osong-eup, Heungdeok-gu, Cheongju, \\ Chungbuk 28160, Republic of Korea \\ ${ }^{2}$ Sustainable Bioresource Research Center, Korea Research Institute of Bioscience and Biotechnology (KRIBB), Yuseoung, \\ Daejeon 305-806, Republic of Korea \\ Correspondence to: Jin Tae Hong, email: jinthong@chungbuk.ac.kr \\ Keywords: neuroinflammation, amyloidogenesis, oxidation, NF- $\kappa B$, Nannochloropsis oceanica \\ Received: January 21, $2017 \quad$ Accepted: March 26, $2017 \quad$ Published: April 20, 2017 \\ Copyright: Choi et al. This is an open-access article distributed under the terms of the Creative Commons Attribution License 3.0 \\ (CC BY 3.0), which permits unrestricted use, distribution, and reproduction in any medium, provided the original author and source \\ are credited.
}

\section{ABSTRACT}

Oxidative stress and neuroinflammation is implicated in the pathogenesis and development of Alzheimer's disease (AD). Here, we investigated the suppressive possibility of ethanol extract of Nannochloropsis oceanica ( $N$. oceanica) on memory deficiency along with the fundamental mechanisms in lipopolysaccharide (LPS)treated mice model. Among several extracts of 32 marine microalgae, ethanol extract of $\boldsymbol{N}$. oceanica showed the most significant inhibitory effect on nitric oxide (NO) generation, NF-KB activity and $\beta$-secretase activity in cultured BV-2 cells, neuronal cells and Raw 264.7 cells. Ethanol extract of $N$. oceanica $(50,100 \mathrm{mg} / \mathrm{kg}$ ) also ameliorated LPS ( $250 \mu \mathrm{g} / \mathrm{kg}$ )-induced memory impairment. We also found that ethanol extract of $\mathbf{N}$. oceanica inhibited the LPS-induced expression of iNOS and COX2. Furthermore, the production of reactive oxygen species (ROS), malondialdehyde (MDA) level as well as glutathione (GSH) level was also decreased by treatment of ethanol extract of $\mathbf{N}$.oceanica. The ethanol extract of $\mathbf{N}$. oceanica also suppresses IKB degradation as well as p50 and p65 translocation into the nucleus in LPS-treated mice brain. Associated with the inhibitory effect on neuroinflammation and oxidative stress, ethanol extract of $N$. oceanica suppressed $A \beta_{1-42}$ generation through down-regulation of APP and BACE1 expression in in vivo. These results suggest that ethanol extract of $\boldsymbol{N}$. oceanica ameliorated memory impairment via anti-inflammatory, anti-oxidant and anti-amyloidogenic mechanisms.

\section{INTRODUCTION}

In recent years, algae have been the oldest living organisms on earth and considered a rich and sustainable source of bioactive compounds such as antioxidants, vitamins, carotenoids as well as fatty acids and amino acids and thus, utilized for biomass as food and feed additives [1, 2]. It is now a global trend to replace artificial antioxidants with natural sources since increased consumption in food supplements as bioactive compounds and in functional foods with safety issues $[3,4]$. Microalgae could be used as alternative and renewable resource since they are a much more diverse biomass among the commercially available natural antioxidant sources [5]. The microalgae evaluation of antioxidant activity of some genera of Chlorella [6, 7], Dunaliella [8], Spirulina [9], Botryococcus [10], Nostoc [11], Phaeodactylum [12], Halochlorococcum [13], Nannochloropsis [14], and Navicula sp. [15] have been reported.

Nannochloropsis sp. including oceanica strain has been identified as well-known sources of eicosapentaenoic acids (EPA), docosahexaenoic acids (DHA), and etc, that are important polyunsaturated fatty acids [16]. These omega-3 unsaturated fatty acids have been reported to 
protect against generation of oxidative stress in neural cells [17] and against dementia including Alzheimer's disease (AD) [18]. EPA and DHA possess healthpromoting effects and preventive activity of cancer, atherosclerosis, heart disease, arthritis and psoriasis [2, 19]. They are important in the brain and blood vessels and are considered to be vital for brain and retina development $[2,20]$. There are a number of alternative EPA and DHA sources, including fungi, bacteria, plants, and microalgae that are already being investigated for commercial use [21]. However, algae are the most plentiful primary producers of EPA and DHA. It was also investigated that ethanol extract of Nannochloropsis sp. exhibits high antioxidant activity and when compared to water and ethanol/water extracts, ethanol extracts have higher activity than water extracts [14]. The ethanol/hexane extract of Nannochloropsis induced higher level of hepatic and plasma EPA and DHA and lowered the cholesterol levels in the rats which were fed hypercholesterolemic diets [22]. Nannochlropsis sp. also prevented As(III) induced reduction in growth variables and proliferation of some contaminant species [23]. It was also reported that Nannochloropsis oceanica (N.oceanica) has significantly promoted antioxidant activity in the amyloid beta-induced oxidative stress in neuronal cells and higher radical scavenging activity $[21,24]$. However, to the extent of our knowledge, no work has been done about the biological effect of Nannochloropsis sp. on neuronal damages [25]. In the present study, the major fatty acid composition of ethanol extract of N.oceanica was determined by gas chromatography coupled to mass spectrometry (GC-MS). The extract contains about 44 types of fatty acids and one of the components was EPA/DHA. We expect EPA from microalgae based on their anti-oxidant and antiinflammatory activities which could be a promising tool for the prevention of inflammatory diseases.

$\mathrm{AD}$ is an age-related neurodegenerative disease characterized by the accumulation of amyloid beta $(A \beta)$, an insoluble peptide causing oxidative damages and neuroinflammation in the brain [26]. Brains of AD patients exhibit a number of pathological abnormalities including loss of synapses and glial function and inflammatory processes [27, 28]. Recently, we and other researchers have also shown that anti-inflammatory and anti-oxidative agents prevent $A \beta$ deposition and brain damages, so these agents could be applicable for the preventive treatment in AD [29]. Furthermore, exposure of lipopolysaccharide (LPS) has been shown to have cognitive and long-term behavioral consequences $[30,31]$. Together, these reports and our results indicate that acute induction of systemic inflammation causes brain inflammation. Although induced systemic inflammation model does not seem to be AD model, systemic LPS administration in mice can result in microglial activation and prolonged pro-inflammatory response that can enhance neuron damage and progressive neurodegeneration. However, a different strategy could be the bridge between
$\mathrm{AD}$ and neuroinflammation since brain inflammation causes neurodegenerative diseases including AD.

Nuclear factor-kappa B $(\mathrm{NF}-\kappa \mathrm{B})$ is a redox transcription factor that influences the levels of oxidative stress in cell $[32,33]$. Expression of several inflammatory genes such as inducible nitric oxide synthase (iNOS) and cyclooxygenase-2 (COX-2) as well as inflammatory cytokines can be regulated by the activation of $\mathrm{NF}-\kappa \mathrm{B}$ [34]. Moreover, the promoter of neuronal BACE1, a limiting enzyme producing $A \beta$ has NF- $\kappa B$ DNA consensus sequences [35]. Thus, blocking NF- $\kappa \mathrm{B}$ could manage AD through the reduction of neuroinflammation, oxidative stress as well as amyloidogenesis [36]. Interestingly, epidemiologic studies have demonstrated that the antiinflammatory and anti-oxidative therapies could decrease the risk of AD via reducing NF- $\kappa \mathrm{B}$ activity [37].

In the present study, we investigated whether ethanol extract of $N$. oceanica has anti-amyloidogenic, anti-inflammatory as well as anti-oxidative properties, and thus ameliorates memory dysfunction in in vivo mice model.

\section{RESULTS}

\section{Screening the inhibitory effects of extracts from marine microalgae on NO generation, NF- $\mathbf{k B}$, $\beta$-secretase activities as well as cell viability}

32 marine microalgae were extracted with several different solvents such as ethanol, hexane and ethyl acetate. $20 \mu \mathrm{g} / \mathrm{mL}$ of extracts were tested for their inhibitory effects on NO generation, NF- $\kappa \mathrm{B}$ and $\beta$-secretase activities. Their anti-inflammatory effect was determined by $\mathrm{NO}$ assay in BV-2 cells, anti-amyloidogenic effect was determined by $\beta$-secretase activity assay in $\mathrm{BV}-2$ cells as well as NF- $\kappa \mathrm{B}$ luciferase activity in Raw 264.7 cells. MTT assay was also used to assess cell viability in neuronal cell. Those results are shown in Table 1. Overall, the anti-inflammatory and amyloidogenic activity of ethanol extract of $N$. oceanica were the most effective. The ethanol extract of $N$. oceanica decreased $37.15 \%$ of NO level, $75.47 \%$ of NF- $\kappa \mathrm{B}$ luciferase activity and $14.04 \%$ of $\beta$-secretase activity induced by LPS.

\section{Effect of ethanol extract of Nannochloropsis oceanica on LPS-induced memory impairment}

To investigate the memory-improving effects of $N$. oceanica by ethanol extract on the LPS-induced memory impairment model, mice were continuously administered ethanol extract of $N$. oceanica $(50,100 \mathrm{mg} / \mathrm{kg})$ in drinking water daily for 4 weeks (from day 1 to day 28), and then $250 \mu \mathrm{g} / \mathrm{kg} /$ day LPS was injected through i.p. daily for 1 week (from day 22 to day 28). All mice were trained for three trials per day for 7 days (Figure 1A). Escape latency and escape distances (Figure 1B, 1C) were determined for 
Table 1: Inhibitory effect of extracts from marine microalgae on NO generation, NF-кB, BACE1 activity as well as cell viability

\begin{tabular}{|c|c|c|c|c|}
\hline $\begin{array}{l}\text { Species } \\
\text { (extraction solvent) }\end{array}$ & $\begin{array}{c}\text { NO inhibition } \\
(\%)\end{array}$ & $\begin{array}{c}\text { NF-кB } \\
\text { inhibition }(\%)\end{array}$ & $\begin{array}{c}\text { BACE1 } \\
\text { inhibition (\%) }\end{array}$ & Cell viability $(\%)$ \\
\hline Isochrysis galbana $(\mathrm{EtOH})$ & 34.79 & 35.60 & No effect & 91.58 \\
\hline Isochrysis galbana (hexane) & 39.56 & 41.71 & 14.19 & 100.4 \\
\hline Pavolva lutheri $(\mathrm{EtOH})$ & 29.67 & 59.09 & 17.60 & 108.68 \\
\hline Pavolva lutheri (hexane) & 39.58 & 78.62 & 21.11 & 76.16 \\
\hline Arthospira plantensis JD105 (EtOH) & 35.89 & 47.67 & 10.05 & 83.5 \\
\hline Arthospira plantensis JD105 (hexane) & 36.81 & 53.25 & 12.32 & 95.15 \\
\hline Nanochloropsis oceanica (EtOH) & 37.15 & 75.47 & 14.04 & 139.44 \\
\hline Tetraselmis suecica $(\mathrm{EtOH})$ & 37.93 & 33.34 & 8.05 & 92.58 \\
\hline Amphidinium carterae $(\mathrm{EtOH})$ & 21.15 & 55.90 & 15.89 & 97.87 \\
\hline Amphidinium carterae (hexane) & 42.82 & 29.95 & 0.57 & 95.16 \\
\hline Amphidinium carterae (ethyl acetate) & 37.16 & 21.76 & 3.38 & 83.80 \\
\hline Chaetoceros gracilis (EtOH) & 22.23 & 54.68 & No effect & 101.04 \\
\hline Chaetoceros gracilis (hexane) & 30.86 & 20.97 & 1.42 & 102.63 \\
\hline Chaetoceros gracilis (ethyl acetate) & 24.85 & 37.54 & 1.71 & 93.01 \\
\hline Caetoceros difficuilis (EtOH) & 30.83 & 55.03 & 0.44 & 96.95 \\
\hline Caetoceros difficuilis (hexane) & 32.28 & 41.97 & 11.61 & 106.88 \\
\hline Caetoceros difficuilis (ethyl acetate) & 34.24 & 56.80 & 4.21 & 87.32 \\
\hline Arthrospira platensis (EtOH) & 12.13 & 37.51 & 9.22 & 90.19 \\
\hline Arthrospira platensis (Hexane) & 19.21 & 39.99 & 16.31 & 115.23 \\
\hline Arthrospira platensis (ethyl acetate) & 9.63 & 40.94 & 10.60 & 106.89 \\
\hline Scenedesmus sp. (EtOH) & 16.86 & 12.09 & No effect & 94.76 \\
\hline Scenedesmus sp. (hexane) & 23 & 8.49 & No effect & 115.24 \\
\hline Scenedesmus sp. (ethyl acetate) & 12.63 & 26.67 & 22.32 & 78.70 \\
\hline Nannochloropsis (EtOH) & 10.37 & 10.56 & No effect & 124.04 \\
\hline Nannochloropsis (hexane) & 2.73 & 33.19 & 0.78 & 111.44 \\
\hline Nannochloropsis (ethyl acetate) & 2.12 & 34.52 & 16.18 & 134.64 \\
\hline Dunaliella saline JD001 (EtOH) & 16.59 & 31.91 & 11.19 & 118.86 \\
\hline Dunaliella saline JD001 (hexane) & 9.18 & 65.33 & 16.48 & 128 \\
\hline Dunaliella saline JD001 (ethyl acetate) & 34.79 & 66.06 & 33 & 138.07 \\
\hline Achnanthidium sp. (EtOH) & 18.75 & 66.50 & 33.12 & 143.5 \\
\hline Achnanthidium sp. (hexane) & 24.2 & 47.98 & 14.67 & 126.62 \\
\hline Achnanthidium sp. (ethyl acetate) & 9.90 & 56.66 & 7.34 & 149.95 \\
\hline
\end{tabular}

Different extracts of 32 marine microalgae were investigated for their anti-inflammatory effect using NO assay, antiamyloidogenic effect using BACE1 activity assay in BV-2 cells and MTT assay in neuronal cells, and NF- $\mathrm{B}$ luciferase activity in Raw 264.7 cell. The values are percentage of decreased activity. 
the effect of ethanol extract of $N$. oceanica on memory impairment. The average escape latency and swimming distance were about $17.5 \pm 2.219 \mathrm{~s}$ and $253.2 \pm 42.26$ $\mathrm{cm}$ after 18 training trials in the control (saline) group. Average escape latency and swimming distance to the platform about $28.28 \pm 1.958 \mathrm{~s}$ and $409.9 \pm 19.75 \mathrm{~cm}$ in LPS-injected mice at day 7 , while a significant decrease to $26.45 \pm 3.174 \mathrm{~s}, 348.2 \pm 57 \mathrm{~cm}$ in the $50 \mathrm{mg} / \mathrm{kg}$ group and $19.92 \pm 3.073 \mathrm{~s}, 276.8 \pm 49.51 \mathrm{~cm}$ in the $100 \mathrm{mg} / \mathrm{kg}$ group were observed in the LPS-injected mice that were given ethanol extract of N.oceanica.

The maintenance of memory function was tested with a probe trial one day after the water maze test. The average time spent in the target quadrant was decreased in the LPS-injected mice $(20.86 \pm 1.926 \%)$ compared to the control mice $(28.67 \pm 2.082 \%)$, but administration of ethanol extract of $N$. oceanica increased average time spent in the target quadrant to $23.35 \pm 2.413 \%(50 \mathrm{mg} / \mathrm{kg})$ and $25.92 \pm 0.8397 \%$ (100 mg/kg) (Figure 1D). One day after the probe trial, a step-through test was performed. The control group exhibited an average step-through latency of $108.8 \pm 19.96 \mathrm{~s}$ in the illuminated compartment, whereas that of the LPS-treated group decreased to 18.54 $\pm 4.305 \mathrm{~s}$. The ethanol extract of N.oceanica-treated mice were recovered to $34.84 \pm 9.06 \mathrm{~s}$ from the LPS-induced step-through latency (Figure 1E).

\section{Effect of the ethanol extract of Nannochloropsis oceanica on the activation of astrocytes and microglia in LPS-injected mice brain}

It is well known that activated neuroglia increases amyloidogenesis and neuroinflammtion. The expression of inflammatory proteins (COX-2 and iNOS) was decreased with the treatment of ethanol extract of $N$. oceanica in the LPS-injected mice brain (Figure 2A). To see whether ethanol extract of $N$. oceanica could inactivate astrocytes and microglia, we performed an immunohistochemical analysis of GFAP (a marker of astrocyte activation) and IBA1-reactive cells (a marker of microglia activation) in the mice brains. GFAP- and IBA1-reactive cell numbers were significantly higher whereas the treatment of ethanol extract of $N$. oceanica reduced the number of GFAP reactive cells in the cortex and hippocampus of LPS injected mice brain (Figure 2B). Paralleled with the immunohistochemical results, Western blot analysis also

A

B
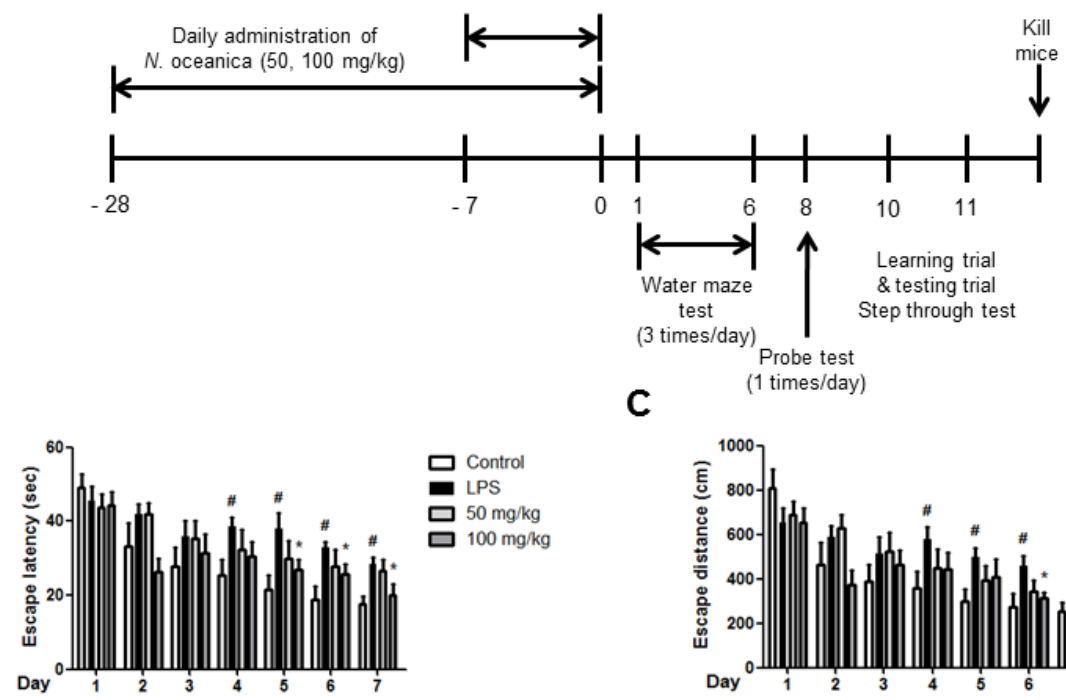

D

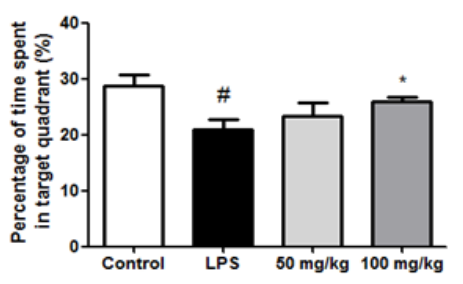

C

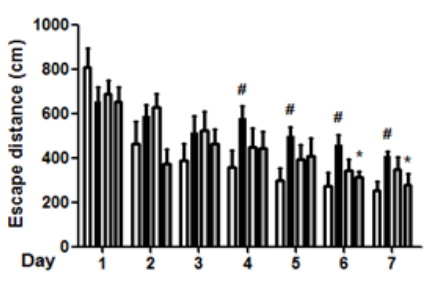

E

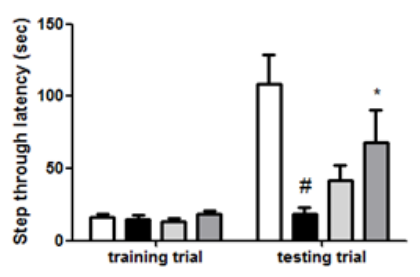

Figure 1: Effect of ethanol extract of Nannochloropsis oceanica on memory impairment. Experimental scheme depicts about ethanol extract of $N$. oceanica treatment and LPS injection (A). To investigate effect of ethanol extract of $N$. oceanica in LPS-induced memory impairment, we performed a water maze test $(\mathbf{B}, \mathbf{C})$, probe test (D) and step-through type passive avoidance test (E). Memory function was determined by the escape latencies $(\mathbf{B}, \mathrm{sec})$ and distance $(\mathbf{C}, \mathrm{cm})$ for 5 days, and time spent in target quadrant $(\mathbf{D}, \%)$ in the probe test after administration of LPS. Each value is mean \pm S.D. from 8 mice. *, Significantly different from control group ( $p<0.05$ ). \#, Significantly different from LPS-treated group $(p<0.05)$. 
showed that expression of COX-2 and iNOS as well as GFAP and IBA-1 was also significantly decreased in brain of ethanol extract of $N$. oceanica treated mice than LPSinjected mice brain (Figure 2C).

\section{Effect of ethanol extract of Nannochloropsis oceanica against the $A \beta_{1-42}$ accumulation and amyloidogenesis as well as activation of $\mathrm{NF}-\kappa \mathrm{B}$ in LPS-injected mice brain}

Accumulation of $A \beta$ could be associated with memory dysfunction. Thus, we determined the effect of ethanol extract of $N$. oceanica on the levels of $A \beta$ in the brains of LPS-injected mice. Increased accumulation of $A \beta$ was found in the brain of LPS-treated mice compared to non-treated mice brain. However, the accumulation of $\mathrm{A} \beta$ was inhibited by ethanol extract of $N$. oceanica treatment (Figure 3A). The ethanol extract of $N$. oceanica treatment also lowered the increased level of $A \beta$ in LPS-injected mice brain (Figure $3 \mathrm{~B}$ ). NF- $\kappa \mathrm{B}$ activity is implicated for amyloidogenesis and neuroinflammation. Thus, we determined NF- $\mathrm{B}$ activation through the detection of $\mathrm{p} 50$,

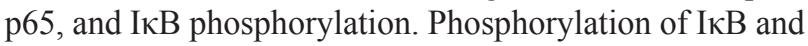
translocation of p50 and p65 were significantly decreased by the treatment of ethanol extract of $N$. oceanica (Figure 3C). We also investigated the levels of APP, BACE1 and C99 proteins using Western blot analysis. The expression of BACE1 and C99 was increased in the brains of LPSinjected mice, and this elevation was reduced by the treatment of ethanol extract of $N$. oceanica (Figure 3D). However, the expression of APP was not significantly changed.

The number of activated (GFAP-positive) astrocytes and accumulation of $A \beta$ (A $\beta$-positive cells) were also determined by double immunofluorescence method. The co-reactive cell number for both markers was significantly increased by LPS injection, but was decreased by ethanol extract of $N$. oceanica treatment (Figure 4A). The coreactive cell number for both activation of microglia (IBA1-postive cells) and $A \beta$ accumulation (A $\beta$-positive cells) was also increased by LPS compared to the number in the non-treated mice brains, but was decreased by ethanol extract of $N$. oceanica treatment (Figure 4B).

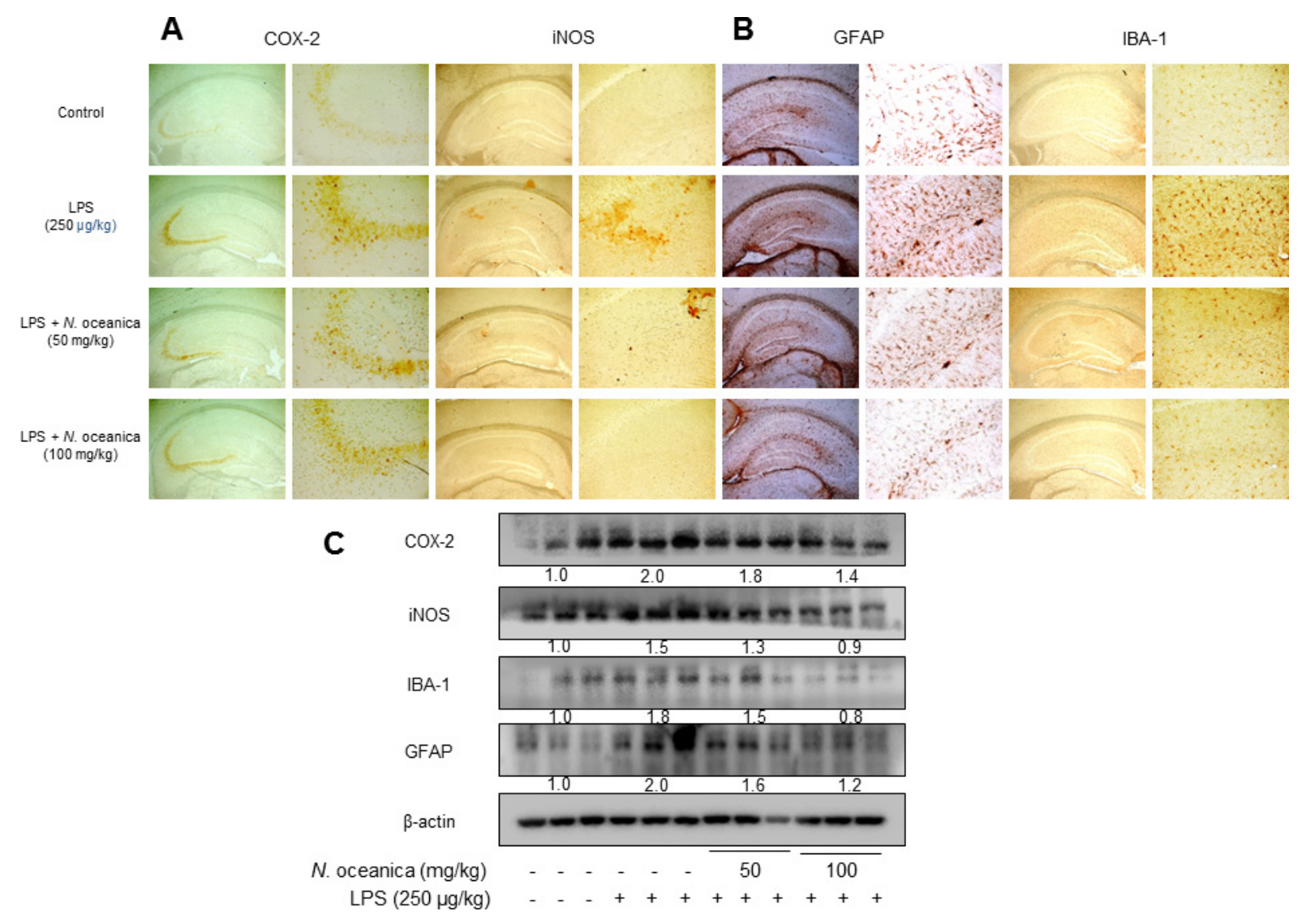

Figure 2: Effect of ethanol extract of Nannochloropsis oceanica on the LPS-induced neuroinflammation and amyloidogenesis in mice brain. Immunostaining of COX-2, iNOS, GFAP and IBA-1 proteins in the hippocampus were performed in $20 \mu \mathrm{m}$-thick sections of mice brain with specific primary antibodies and the biotinylated secondary antibodies (A, B). The expression of COX-2, iNOS, GFAP and IBA-1 were detected by Western blotting using specific antibodies in the mice brain. Each blot is representative of three experiments (C). For the cropped images, samples were run in the same gels under same experimental conditions and processed in parallel. Each band is representative for three experiments. 


\section{Ethanol extract of Nannochloropsis oceanica inhibits LPS-induced oxidative stress}

Ethanol extract of $N$. oceanica decreased superoxide anion production in the mice brain. Intracellular superoxide radical production was measured by dihydroethidium [38] in the brain. Furthermore, another study has shown that local LPS administration contributes the activation of astroglial $/ \mathrm{microglial}$ cells in the place of this toxin administration. Additionally, it was reported that the damage to the brain can be caused by inflammation and oxidative stress after longer exposure to LPS for 7 days or more $[39,40]$. The accumulation of excessive intracellular ROS with increased enzymatic sources characterizes the oxidative stress [41]. Although the intensity of oxidative stress is different since oxidation usually occurs at a shorter time, systemic LPS treated for a long time will damage the brain with exposure to oxidative stress. The brain sections were double stained with DHE (red) and DAPI staining (blue). The ethanol extract of $N$. oceanicatreated mice had a significant decrease in the intensity of DHE signals compared to the LPS-injected mice (Figure 5A). We also evaluated MDA contents and GSH levels, which are indicators of oxidative stress. The MDA and GSH levels were significantly increased in the brains of LPS-injected mice compared to control mice. However, contrast to LPS-injected mice, mice treated with ethanol extract of $N$. oceanica showed lower MDA (Figure 5B) and GSH levels (Figure 5C).

\section{DISCUSSION}

In this study, we found that ethanol extract of $N$. oceanica suppressed neuroinflammation, oxidative

\section{A}

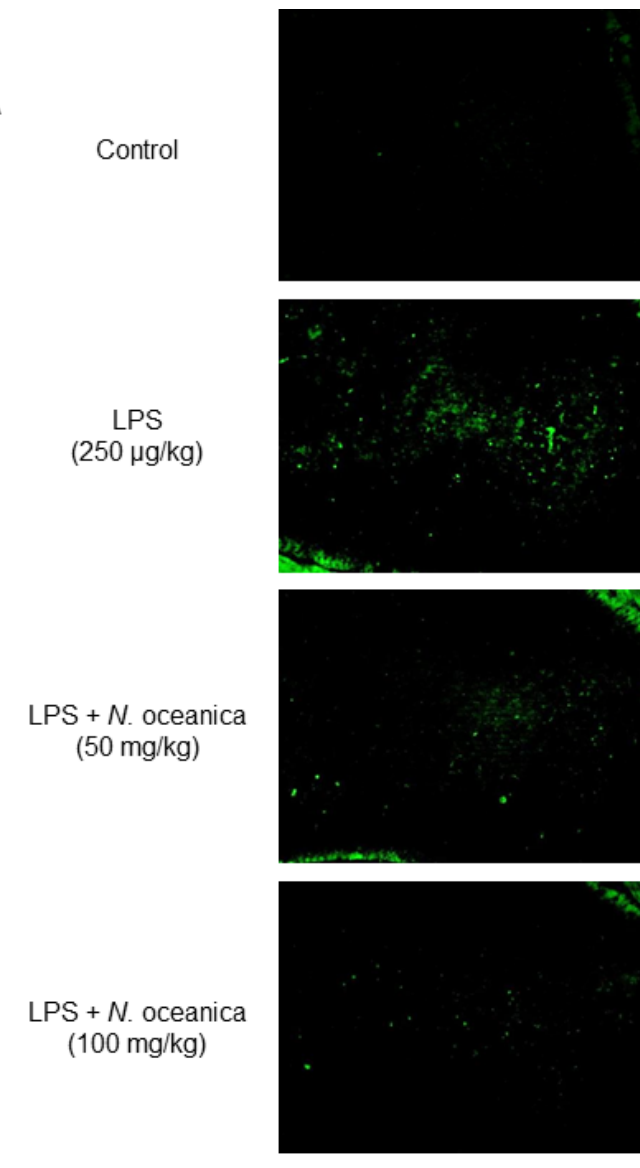

B

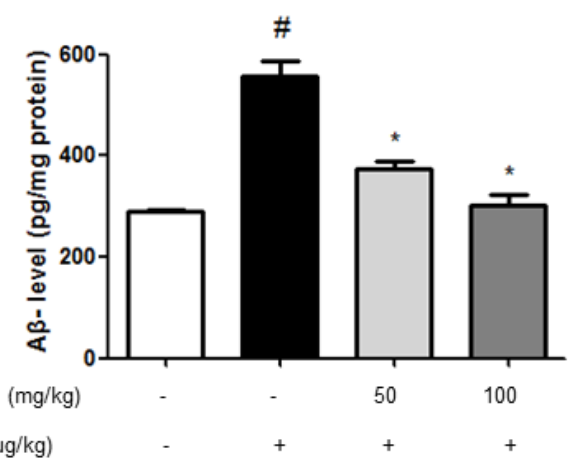

LPS $(250 \mu \mathrm{g} / \mathrm{kg})$

C

p50
p65

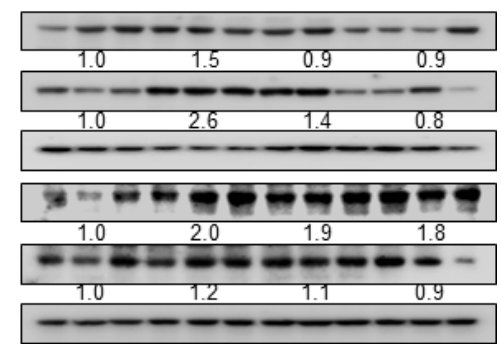

D APP

BACE1

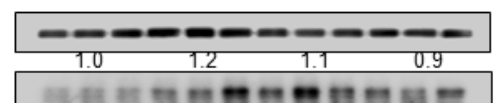

C99

$\beta$-actin

N. oceanica $(\mathrm{mg} / \mathrm{kg})$

$\operatorname{LPS}(250 \mu \mathrm{g} / \mathrm{kg})$

Figure 3: Effect of ethanol extract of Nannochloropsis oceanica on A $\beta$ accumulation and expression of amyloidogenic proteins in the mouse brain. $A \beta$ accumulation in the brains of LPS-injected mice was determined by thioflavin S staining (A). The level of $A \beta_{1-42}$ was assessed by using a specific $A \beta$ ELISA as described in Methods (B). Phosphorylation of I $\mathrm{B}$, and p50 and p65 translocation were detected by Western blotting using specific antibodies in mice brain. $\beta$-actin and HistonH1 protein was used as an internal control (C). The expression of APP, C99 and BACE1 was detected by Western blotting using specific antibodies in mice brain. $\beta$-actin protein was used as an internal control (D). Each blot is representative for three experiments. Values measured from each group of mice were calibrated by amount of protein and expressed as mean \pm S.D. $(n=8)$. *, Significantly different from control group $(\mathrm{p}<0.05)$. \#, Significantly different from LPS-treated group $(\mathrm{p}<0.05)$. 


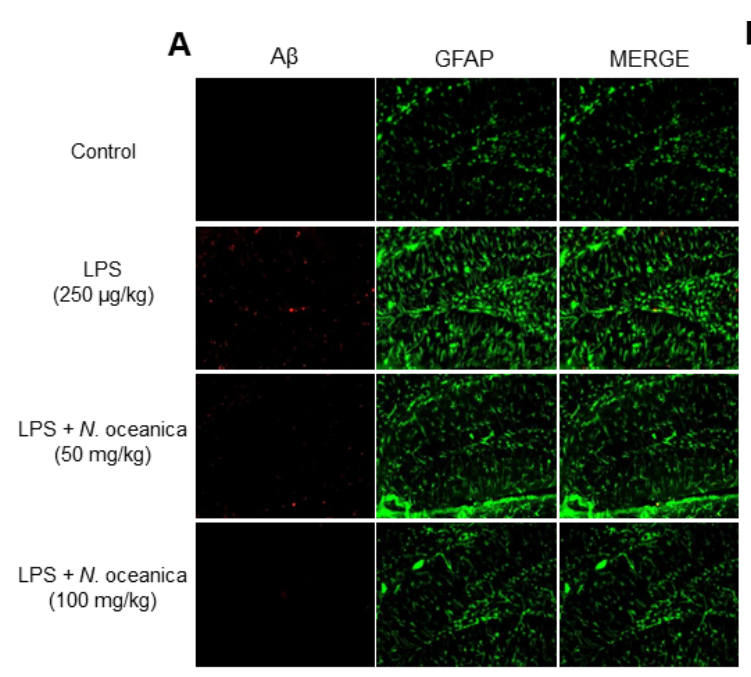

B $\quad$ IBA-1 MERGE
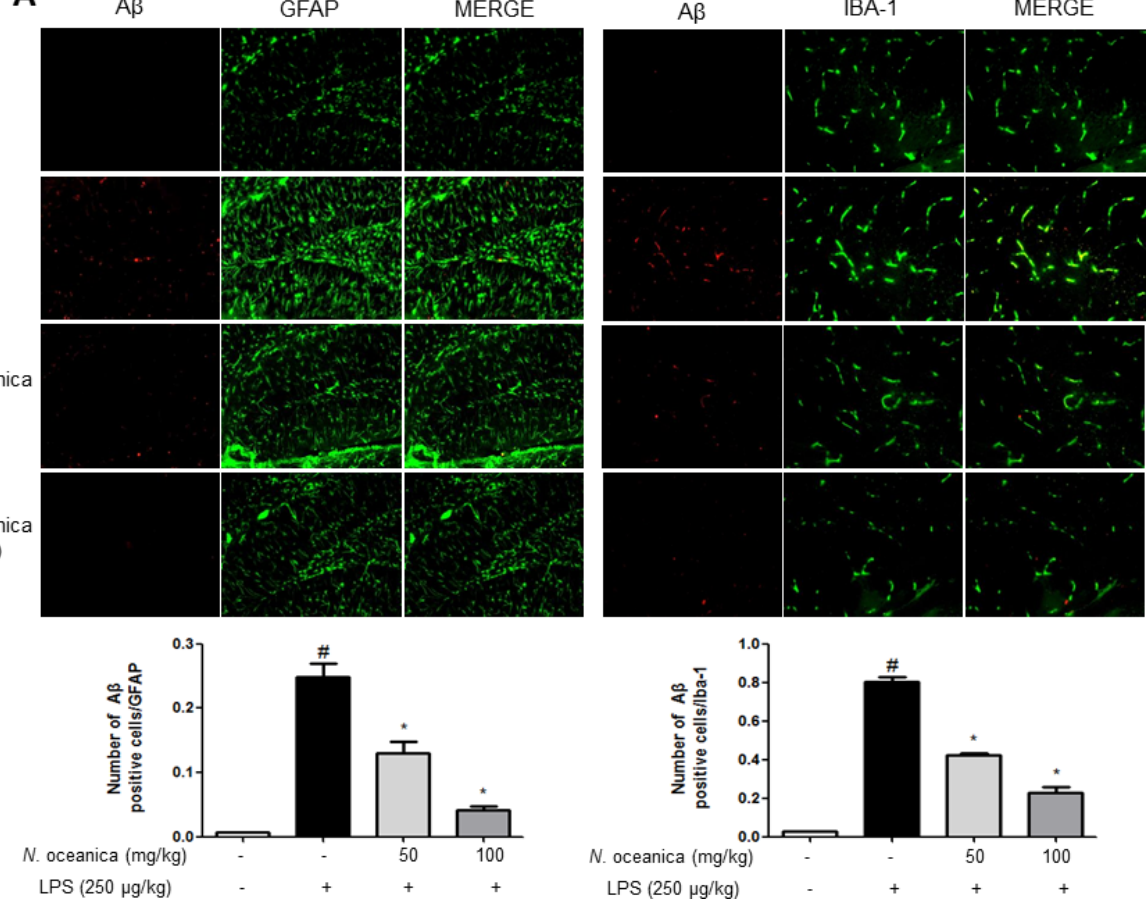

Figure 4: Effect of ethanol extract of Nannochloropsis oceanica on the LPS-induced neuroinflammation. Staining was performed in $20 \mu \mathrm{m}$-thick sections of mice brain. Confocal microscope observation was performed as described in the Methods section. Immunostaining of GFAP (green) and $A \beta_{1-42}$ (red) protein in the hippocampus was performed with specific primary antibodies, and fluorescence was developed using Alexa 488-conjugated anti-goat and Alexa 568-conjugated anti-rabbit secondary antibodies (A). IBA-1 (red) and $A \beta_{1-42}$ (green) protein in the hippocampus was performed with specific primary antibodies, and fluorescence was developed using Alexa 488-conjugated anti-mouse and Alexa 568-conjugated anti-rabbit secondary antibodies (B). Similar patterns were observed in five mice brains.

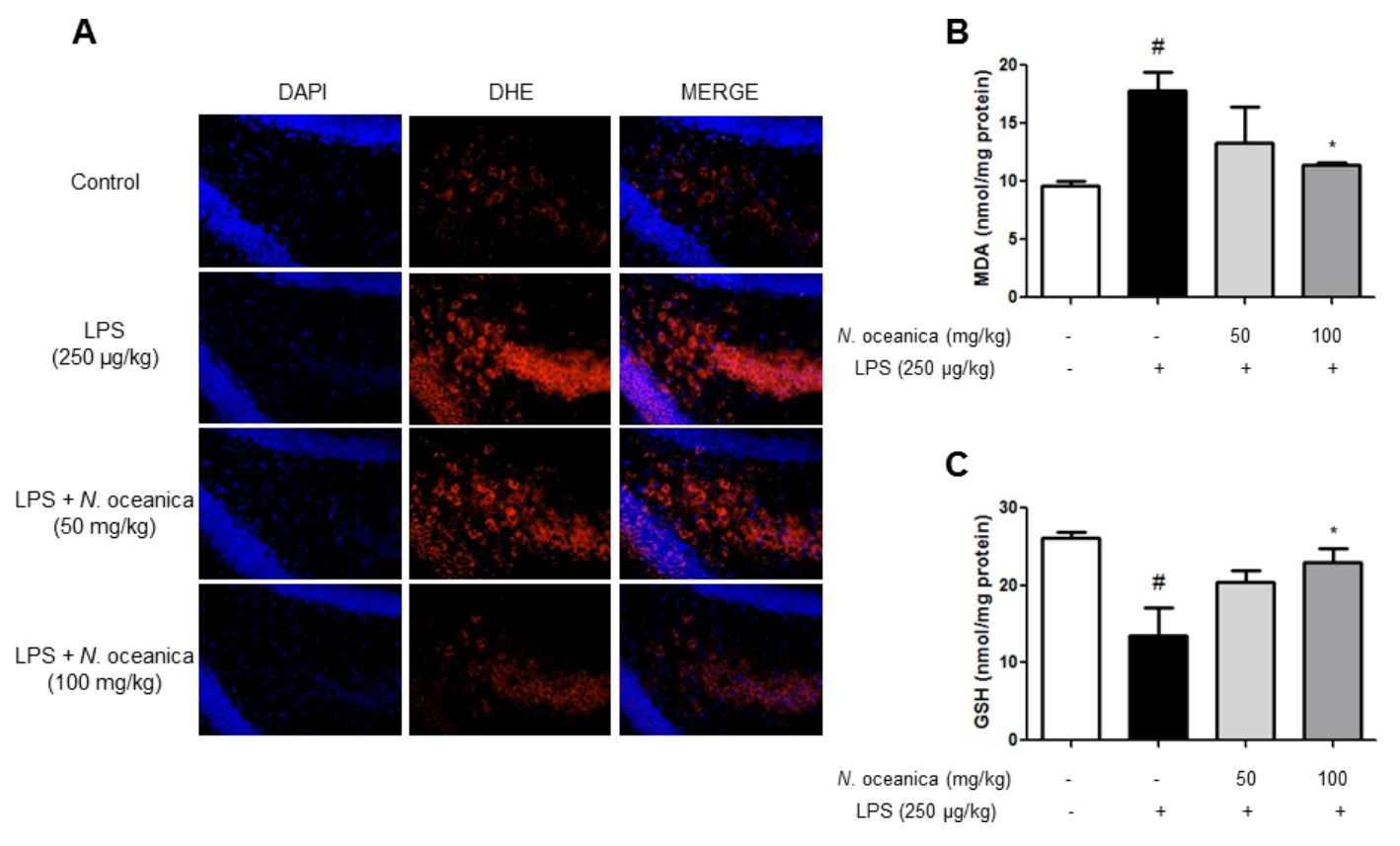

Figure 5: Effect of ethanol extract of Nannochloropsis oceanica on the LPS-induced oxidative stress in the mouse brain. Intracellular superoxide radical production was measured by dihydroethidium in the brain. The brain sections were double stained with DHE (red) and DAPI staining (blue) (A). MDA (B) and GSH level (C) were assessed by using a specific detection kit as described in Methods. Values measured from each group of mice were calibrated by amount of protein and expressed as mean \pm S.D. $(n=8)$. *, Significantly different from control group $(\mathrm{p}<0.05)$. \#, Significantly different from LPS-treated group $(\mathrm{p}<0.05)$. 
stress and amyloidogenesis in LPS-induced AD model, and thus ameliorated memory impairment. Growing epidemiological evidences have suggested that oxidative stress and neuroinflammation may contribute to the pathogenesis of AD $[42,43]$. Recently, several researchers including ours reported that systemic administration of LPS induces the release of proinflammatory mediators and free radicals, and causes oxidative brain damage [27, 44]. Furthermore, systemic administration of LPS has been contributed to result in increased APP processing by $\beta$-secretase and intracellular accumulation of $\mathrm{A} \beta$ as well as cognitive impairment since LPS induces amyloidogenesis with concomitant increased neuroinflammation and oxidative damages [45, 46]. Furthermore, conventional transgenic models of $\mathrm{AD}$ are undoubtedly the basis of understanding several mechanisms in AD. However, the different method could be the bridge between AD and neuroinflammation since brain inflammation causes neurodegenerative diseases including AD. Moreover, administration of anti-inflammatory and anti-oxidative agents reduces the risk and delays the neuropathologic features of $\mathrm{AD}[47,48]$. In this present study, we reported for the first time so far that ethanol extract of $N$. oceanica, one of microalgae could decrease amyloidogenesis and memory deficiency via the prevention of oxidative brain damage and neuroinflammation.

The exact mechanism of amyloidogenesis is not clear. However, it is remarkable that NO and ROS have been implicated in the activation of BACE1 expression, where ROS has been hypothesized to increase $\beta$-secretase $[49,50]$. In our previous study, L-theanine and EGCG which are antioxidant compounds showed antineuroinflammatory responses and anti-amyloidogenic activity through anti-oxidant mechanisms [51, 52]. Extensive evidence exists that ROS generation increases with $A \beta$ as well as $A \beta$ can also induce oxidative stress [53]. Alternatively, the inhibitory effect on NF- $\kappa B$ could be also associated with its anti-amyloidogenic effects. NF$\kappa \mathrm{B}$ is involved in the expression of inflammatory genes such as COX-2 and iNOS [54]. Moreover, the promoters of APP and BACE1 contain NF- $\mathrm{KB}$ sites, which derive transcription [35]. Some NSAIDs, including indomethacin and flurbiprofen have been shown to be effective at decreasing amyloidogenesis by targeting NF- $\kappa \mathrm{B}[55,56]$. Additionally, numerous compounds which inhibit NF$\kappa \mathrm{B}$ were reported to attenuate amyloidogenesis such as sorafenib [57], artemisinin [58] and L-theanine [52]. We previously found that activation of $\mathrm{NF}-\kappa \mathrm{B}$ contributes to increasing $\beta$-secretase activity in neuronal cells expressing mutant PS2 [59], and also demonstrated that treatment of EGCG inhibits $\beta$-secretase activity via inhibition of NF$\kappa \mathrm{B}$ pathways in PS2 mice because it is a well-known antiinflammatory and anti-oxidant agent [60]. In the present study, we found that ethanol extract of N.oceanica reduced ROS and MDA generation, and NF- $\mathrm{B}$ activation. Thus, these antioxidative properties and inhibitory effect on
$\mathrm{NF}-\kappa \mathrm{B}$ are associated with anti-amyloidogenic effects. Additionally, activation of astrocytes and microglia has been known to increase expression of BACE1, thereby increasing $A \beta$ generation [61]. The increased expression of BACE1 after induction of chronic gliosis was not only associated with experimental mice brain but also in the brains of $\mathrm{AD}$ patients caused by $\mathrm{A} \beta$ plaques with activated microglia [62].

Thus, the present data indicated that the antiinflammatory properties of ethanol extract of $N$. oceanica could also be associated with anti-amyloidogenesis through inactivation of microglia in the brain. Taken together, these data indicated that anti-oxidative effects, anti-neuroinflammatory effects and amyloidogenic effects of ethanol extract of $N$. oceanica could lead memory recovery. We recently found that the main component of N.oceanica is EPA, which has antioxidant and anti-inflammatory effects in vitro and in vivo. There are many sources of EPA, and the different composition of EPA could have an effect on differential pharmacological activities. Thus, we are studying the differential antioxidant and neuroinflammatory activities of EPA isolated from the ethanol extract of N.oceanica. An oral administration of $100 \mathrm{mg} / \mathrm{kg} /$ day for 4 weeks in our study did not cause any negative side effects. Thus ethanol extracts or its major component, EPA could be applicable for the development of functional food or drug for treatment of AD.

\section{MATERIALS AND METHODS}

\section{Ethical approval}

The experimental protocols were carried out according to the guidelines for animal experiments of the Faculty of Disease Animal Model Research Center, Korea Research Institute of Bioscience and Biotechnology (Daejeon, Korea) as well as Institutional Animal Care and Use Committee (IACUC) of Laboratory Animal Research Center at Chungbuk National University, Korea (CBNUA-929-16-01). All efforts were made to minimize animal suffering and to reduce the number of animals used. All mice were housed in a cage, three mice per cage, with automatic temperature control (21$\left.25^{\circ} \mathrm{C}\right)$, relative humidity $(45-65 \%)$, and $12 \mathrm{~h}$ light-dark cycle illuminating from 08:00 a.m. to 08:00 p.m. Food and water were available ad libitum. They were fed a pellet diet consisting of crude protein $20.5 \%$, crude fat $3.5 \%$, crude fiber $8.0 \%$, crude ash $8.0 \%$, calcium 0.5 $\%$, phosphorus $0.5 \%$ per $100 \mathrm{~g}$ of the diet (obtained from Daehan Biolink, Chungcheongbuk-do, Korea). During this study, all mice were specially observed for normal body posture, piloerection, ataxia, urination, etc. 2 times per day to minimize their pain and discomfort. 


\section{Materials}

The strains of all tested microalgae including Nannochloropsis oceanica were supplied from Natural Live Plankton (NLP, Busan, Republic of Korea) and identified by one of the authors (HSK)(Batch No. 285F093). Grinded microalgae strain was disrupted by sonicator for $3 \mathrm{~h}$. Then, finely powdered and dried microalgae were extracted with $100 \%$ of EtOH, Hexane and Ethyl acetate one time $(6 \mathrm{~L} \times 1,30 \mathrm{~min})$ at room temperature by a funnel shaker. They were then passed to sedimentation tanks, which aim to remove the settleable solids by gravity. After sedimentation and filtration of extract, the collected filtrate, the extract solvent layer was dried overnight using a rotary vacuum evaporator and then, concentrated under reduced pressure. The main components in ethanol extract of $N$. oceanica are 12.8 $\%$ of docosapentaenoic acid (C22 : 6, DHA), $5.3 \%$ of eicosapentaenoic acid (C20 : 5, EPA), $15.4 \%$ of palmitic acid, $9.6 \%$ of cholesterol, $11.9 \%$ of palmitoleic acid, 4.5 $\%$ of 1-dodecanol 3, 7, 11-trimethyl-, $3.3 \%$ of oleic acid chloride, and etc. The resulting products were further used for assay. Different extracts of 32 marine microalgae were investigated for their anti-inflammatory effect using NO assay, NF- $\mathrm{kB}$ luciferase activity and anti-amyloidogenic effect using BACE1 activity assay. The ethanol extract of Nannochloropsis oceanica was the most effective, so we administered ethanol extract of $N$. oceanica in in vivo experiment. The ethanol extract of $N$. oceanica (final concentration of 50 and $100 \mathrm{mg} / \mathrm{mL}$ ) was dissolved in $100 \%$ of dimethyl sulfoxide (DMSO), and stored at $-20^{\circ} \mathrm{C}$ until use. The ethanol extract of $N$. oceanica (final concentration of $10 \mathrm{mg} / \mathrm{mL}$ ) was dissolved in $100 \%$ of DMSO, and aliquots were stored at $-20^{\circ} \mathrm{C}$ until use in in vivo. The LPS was purchased from Sigma (serotype O55:B5, Sigma, St. Louis, MO. USA). The LPS (final concentration of $1 \mathrm{mg} / \mathrm{mL}$ ) was dissolved in PBS, and aliquots in PBS were stored at $-20^{\circ} \mathrm{C}$ until use.

\section{Animal experiment}

Eight-to-ten week old male imprinting control region (ICR) mice (Daehan Biolink, Chungcheongbukdo, Korea) were maintained and handled in accordance with the humane animal care and use guidelines of Korean FDA. ICR mice were randomly divided into four groups with 10 mice in each group: (I) Control group; (II) LPS group; (III) ethanol extract of $N$. oceanica $(50 \mathrm{mg} / \mathrm{kg})+$ LPS group control group; and (IV) ethanol extract of $N$. oceanica $(100 \mathrm{mg} / \mathrm{kg})+$ LPS group. The ethanol extract of $N$. oceanica was given to groups (III) and (IV) in drinking water daily for 4 weeks. Intraperitoneal (i.p.) injection of LPS $(250 \mu \mathrm{g} / \mathrm{kg})$ was administered to all groups except for the control group on the 4th week for 7 days. Control mice were given an equal volume of vehicle instead. The behavioral tests of learning and memory capacity were assessed using the water maze, probe and passive avoidance test. Mice were sacrificed after behavioral tests by $\mathrm{CO}_{2}$ asphyxiation.

\section{Morris water maze}

A memory test was performed by the Morris's water maze test as described elsewhere with SMART-CS (Panlab, Barcelona, Spain) program and equipment [63].

\section{Probe test}

Memory consolidation was tested with a probe test after 24h the water maze test with SMART-LD program (Panlab, Barcelona, Spain). Consolidated spatial memory was estimated by the time spent in the target quadrant area as described elsewhere [63].

\section{Passive avoidance test}

The passive avoidance response was determined using a "step-through" apparatus (Med Associates, Georgia, VT) as described elsewhere [63].

\section{Microglial BV-2 cells culture}

Microglial BV-2 cell cultures were prepared as previously described [64]. The cultured cells were treated simultaneously with LPS $(1 \mu \mathrm{g} / \mathrm{mL})$ and several concentrations $(20 \mu \mathrm{g} / \mathrm{mL})$ of marine microalgae were dissolved $100 \%$ of DMSO. The cells were harvested after $24 \mathrm{~h}$. NO level and $\beta$-secretase activity were determined.

\section{Neuronal cell culture}

The Sprague-Dawley rats were maintained in accordance with the policy of the National Institute of Toxicological research, which is in accordance with the Korea Food and Drug Administration's guideline for the care and use of laboratory animals. Sprague-Dawley rats weighing 200-300 g were housed under $12 \mathrm{~h}$ light/ dark cycles, at $23^{\circ} \mathrm{C}$ and $60 \pm 5 \%$ humidity. All animals had free access to food (Samyang Foods, Seoul, Korea) and water. Cerebral cortical cells were isolated from neonatal rat brains (Day 1) in PBS (0.1 mol). Briefly, cerebral cortices were removed and incubated for 15 min in $\mathrm{Ca} 2+-$ and $\mathrm{Mg} 2+$-free Hanks' balanced saline solution (Life Technologies) containing 0.2\% trypsin. Cells were dissociated by trituration and plated into polyethyleneimine-coated plastic or glass-bottomed culture dishes containing minimum essential medium with Earle's salts supplemented with $10 \%$ heat-inactivated fetal bovine serum, $2 \mathrm{mM}$ l-glutamine, $1 \mathrm{mM}$ pyruvate, $20 \mathrm{mM}$ $\mathrm{KCl}, 10 \mathrm{mM}$ sodium bicarbonate, and $1 \mathrm{mM}$ Hepes ( $\mathrm{pH}$ 7.2). Following cell attachment (3-6 h after plating), the culture medium was replaced with a neurobasal medium 
containing B27 supplements (Life Technologies). The cells were cultured in the neuronal cell culture medium for 3 days, and then further cultured in a neuronal cell culture medium (NCM) with or without $20 \%$ astrocyte culture media (ACM). Experiments were performed with 4 to 6 -day-old cultures; more than $90 \%$ of the cells in these cultures were neurons, and the remainder were astrocytes, as judged by cell morphology and by immunostaining with antibodies against neurofilaments and glial fibrillary acidic protein.

\section{RAW264.7 cell culture}

The murine macrophage-like cell line RAW 264.7 was obtained from the American Type Culture Collection (Manassas, VA, USA), were cultured in Dulbecco's modified Eagle's medium (DMEM, Gibco-BRL) with 10\% heat-inactivated fetal bovine serum (FBS) and penicillin/ streptomycin $(100 \mathrm{U} / \mathrm{mL})$ at $37^{\circ} \mathrm{C}$ under humidified air contacting $5 \% \mathrm{CO}_{2}$, inside a $\mathrm{CO}_{2}$ incubator as previously described [65].

\section{Brain collection and preservation}

After behavioral tests, mice were perfused with phosphate-buffered saline (PBS) with heparin under inhaled $\mathrm{CO}_{2}$ anesthetization. The brains were immediately removed from the skulls and divided into left brain and right brain. One stored at $-80^{\circ} \mathrm{C}$, the other was fixed in 4 $\%$ paraformaldehyde for $72 \mathrm{~h}$ at $4^{\circ} \mathrm{C}$ and transferred to 30 $\%$ sucrose solutions, respectively.

\section{Immunohistochemical staining}

Immunohistochemical staining was performed as described previously [66]. The sections were incubated overnight with a rabbit/mouse polyclonal antibody against GFAP; SC-33673 (1:300, Santa Cruz Biotechnology Inc. Santa Cruz, CA, USA), IBA-1; NB100-1028, iNOS; NB300-605 (1:300; Novus Biologicals, Inc., Littleton), COX-2; \#12282 (1:300; Cell Signaling Technology, Inc., Beverly, MA). In order to prevent nonspecific staining, a blocking step was included. Sections were incubated at room temperature for $2 \mathrm{~h}$ with 5\% bovine serum albumin [67] (in PBS), and then incubated overnight at $4{ }^{\circ} \mathrm{C}$ with the primary antibody in blocking solution (5\% BSA). Immunohistochemical staining was performed on 8 mice per group (3 sections per each mouse).

\section{Western blot analysis}

Western blotting was performed as described previously [64]. To detect target proteins, specific antibodies against APP; NB110-55461, IBA-1; NB1001028, iNOS; NB300-605 (1:1000, Novus Biologicals, Inc., Littleton), BACE1; \#5606, COX-2; \#12282 (1:1000, Cell Signaling Technology, Inc., Beverly, MA, USA), GFAP;
SC-33673, p50; SC-114, p65; SC-8008, IкB; SC-371, phospho-IкB; SC-8404, $\beta$-actin; SC-47778, and Histone H1; SC-8030 (1:1000, Santa Cruz Biotechnology Inc. Santa Cruz, CA, USA) were used. The blots were then incubated with the corresponding conjugated goat antirabbit; SC-2004 or goat anti-mouse; SC-2005 or donkey anti-goat; SC-2020 IgG-horseradish peroxidase (HRP) (1:5000; Santa Cruz Biotechnology Inc. Santa Cruz, CA, USA) secondary antibodies. Immunoreactive proteins were detected with an enhanced chemiluminescence Western blotting detection system. The relative density of the protein bands was quantified with Image J software.

\section{Measurement of $A \beta_{1-42}$}

Lysates of brain tissue were obtained through a protein extraction buffer containing protease inhibitor. $\mathrm{A} \beta_{1-42}$ levels were determined using each specific ELISA Kit (CUSABIO) using a microplate absorbance reader (Sunrise $^{\mathrm{TM}}$, TECAN, Switzerland) after adding stop solution as described elsewhere [68].

\section{Thioflavin S staining}

The thioflavin $\mathrm{S}$ staining was examined using a fluorescence microscope (Axio Observer A1, Carl Zeiss, Oberkochen, Germany) $(\times 100)$ as described elsewhere [69].

\section{Fluorescence microscopy}

The fixed cells and brain sections were exposed to the following primary antibodies: GFAP (1:100, Santa Cruz Biotechnology Inc. Santa Cruz, CA, USA), IBA-1 (Abcam, Inc., Cambridge, MA, USA), and A $\beta$ (1:100, Cell Signaling Technology, Inc. Beverly, MA) at room temperature for $2 \mathrm{~h}$. After incubation, the cells were washed twice with ice-cold PBS and incubated with an anti-rabbit or mouse or goat secondary antibody conjugated to Alexa Fluor $488 \mathrm{~nm}$ or $568 \mathrm{~nm}$ (InvitrogenMolecular Probes, Carlsbad, CA) at room temperature for $1 \mathrm{~h}$. Immunofluorescence images were acquired using an inverted fluorescent microscope Zeiss Axiovert $200 \mathrm{M}$ (Carl Zeiss, Thornwood, NY) $(\times 200)$.

\section{Nitric oxide determination}

Cells were grown in 24-well plates and then incubated with or without LPS $(1 \mu \mathrm{g} / \mathrm{mL})$ in the absence or presence of various concentrations of microalgae for 24 $\mathrm{h}$. The nitrite accumulation in the supernatant was assessed by NO detection kit (iNtRON, Kyungki-do, Korea). The absorbance at $520 \mathrm{~nm}$ was measured in a microplate absorbance reader, and a series of known concentrations of sodium nitrite was used as a standard. 


\section{Oxidative stress assay}

Hydrogen peroxides were measured according to the manufacturer's instructions (Cell Biolabs, San Diego, CA). Total glutathione (GSH), and malondialdehyde (MDA) were measured according to the manufacturer's instructions (Cayman chemical, USA). To perform assay, the brain tissues were homogenized, then normalized to protein concentration. Superoxide production in the brain was detected by dihydroethidium [38] staining (SigmaAldrich). Brains were incubated with $5 \mu \mathrm{M}$ DHE for $30 \mathrm{~min}$ at $37^{\circ} \mathrm{C}$ in a humidified chamber protected from light. The average fluorescence intensity of the nuclei was then analyzed using Image Pro-Plus software (Media Cybernetics, Inc.).

\section{Assay of $\beta$-secretase activities}

$\beta$-secretase activity in the mice brains was determined using a commercially available $\beta$-secretase activity kit (Abcam, Inc, Cambridge, MA, USA) using a fluorescence spectrometer (Gemini EM, Molecular Devices, California, USA) as described elsewhere [69].

\section{Reporter gene assay}

Cells were plated at $1 \times 10^{5}$ cells/well in a 24 -well culture plate and transiently transfected with NF-кBluciferase reporter (Affymetrix Inc., Santa Clara, CA, USA) or pNF-kB-luciferase reporter (Stratagene, Cedar Cree, CA, USA) using Lipofectamine LTX \& PLUS (Invitrogen) in OPTI-MEM media (Invitrogen, Carlsbad, CA, USA) according to the manufacturer's instructions. The transfected cells were treated with LPS $(1 \mu \mathrm{g} / \mathrm{mL})$ in the absence or presence of various concentrations of Nannochloropsis oceanica for $24 \mathrm{~h}$. The reporter gene activity was assayed using the luciferase assay kit (Promega Co., Madison, WI, USA), measured by a luminescence counter (Wallac Victor2 1420, PerkinElmer Inc., Waltham, MA, USA).

\section{Statistical analysis}

All statistical analysis was performed with GraphPad Prism 5 software (Version 5.03; GraphPad software, Inc., San Diego, CA). Group differences were analyzed by two-way ANOVA followed by Dunnette's post hoc test. All values are presented as mean \pm S.D. Significance was set at $\mathrm{p}<0.05$ for all tests.

\section{Author contributions}

J.Y.C. and J.T.H. designed the experiments and wrote the manuscript. J.Y.C., C.J.H. and H.S.K. performed the experiments. J.Y.C., C.J.H., H.S.K., S.B.H. and J.T.H. analyzed the data. J.T.H. supervised the whole paper. All authors have reviewed the manuscript.

\section{ACKNOWLEDGMENTS}

This research was supported by the National Research Foundation of Korea [NRF] Grant funded by the Korea government (MSIP) (No. MRC, 2008-0062275), by the Marine Biotechnology Program (No. 20150184) Funded by Ministry of Oceans and Fisheries, Korea, and by the Ministry of Trade, Industry \& Energy (MOTIE, 1415126993) through the fostering project of Osong Academy-Industry Convergence (BAIO).

\section{CONFLICTS OF INTEREST}

The authors declare that they have no competing interest.

\section{REFERENCES}

1. Safafar H, van Wagenen J, Moller P, Jacobsen C. Carotenoids, phenolic compounds and tocopherols contribute to the antioxidative properties of some microalgae species grown on industrial wastewater. Mar Drugs. 2015; 13:7339-7356.

2. Talero E, Garcia-Maurino S, Avila-Roman J, RodriguezLuna A, Alcaide A, Motilva V. bioactive compounds isolated from microalgae in chronic inflammation and cancer. Mar Drugs. 2015; 13:6152-6209.

3. Carocho M, Ferreira IC. A review on antioxidants, prooxidants and related controversy: natural and synthetic compounds, screening and analysis methodologies and future perspectives. Food Chem Toxicol. 2013; 51:15-25.

4. Lordan S, Ross RP, Stanton C. Marine bioactives as functional food ingredients: potential to reduce the incidence of chronic diseases. Mar Drugs. 2011; 9:1056-1100.

5. de Morais MG, Vaz Bda S, de Morais EG, Costa JA. Biologically active metabolites synthesized by microalgae. BioMed Res Int. 2015; 2015:835761.

6. Tang H, Chen M, Garcia ME, Abunasser N, Ng KY, Salley SO. Culture of microalgae Chlorella minutissima for biodiesel feedstock production. Biotechnol Bioeng. 2011; 108:2280-2287.

7. Guzman S, Gato A, Calleja JM. Antiinflammatory, analgesic and free radical scavenging activities of the marine microalgae Chlorella stigmatophora and Phaeodactylum tricornutum. Phytotherap Res. 2001; 15:224-230.

8. Chidambara Murthy KN, Vanitha A, Rajesha J, Mahadeva Swamy M, Sowmya PR, Ravishankar GA. In vivo antioxidant activity of carotenoids from Dunaliella salina--a green microalga. Life Sci. 2005; 76:1381-1390.

9. Dartsch PC. Antioxidant potential of selected Spirulina platensis preparations. Phytotherapy Res. 2008; 22:627-633.

10. Rao AR, Sarada R, Baskaran V, Ravishankar GA. Antioxidant activity of Botryococcus braunii extract 
elucidated in vitro models. J Agric Food Chem. 2006; 54:4593-4599.

11. Wang G, Chen K, Chen L, Hu C, Zhang D, Liu Y. The involvement of the antioxidant system in protection of desert cyanobacterium Nostoc sp. against UV-B radiation and the effects of exogenous antioxidants. Ecotoxicol Environ Saf. 2008; 69:150-157.

12. Kawee-ai A, Kuntiya A, Kim SM. Anticholinesterase and antioxidant activities of fucoxanthin purified from the microalga Phaeodactylum tricornutum. Nat Product Commun. 2013; 8:1381-1386.

13. Karawita R, Senevirathne M, Athukorala Y, Affan A, Lee YJ, Kim SK, Lee JB, Jeon YJ. Protective effect of enzymatic extracts from microalgae against DNA damage induced by H2O2. Mar Biotechnology. 2007; 9:479-490.

14. Maadane A, Merghoub N, Ainane T, El Arroussi H, Benhima R, Amzazi S, Bakri Y, Wahby I. Antioxidant activity of some Moroccan marine microalgae: Pufa profiles, carotenoids and phenolic content. J Biotechnol. 2015; 215:13-19.

15. Fimbres-Olivarria D, Lopez-Elias JA, Carvajal-Millan E, Marquez-Escalante JA, Martinez-Cordova LR, MirandaBaeza A, Enriquez-Ocana F, Valdez-Holguin JE, BrownBojorquez F. Navicula sp. sulfated polysaccharide gels induced by $\mathrm{Fe}(\mathrm{III})$ : rheology and microstructure. Int J Mol Sci. 2016; 17.

16. Ma XN, Chen TP, Yang B, Liu J, Chen F. Lipid production from nannochloropsis. Mar Drugs. 2016; 14.

17. Kumar PR, Essa MM, Al-Adawi S, Dradekh G, Memon MA, Akbar M, Manivasagam T. Omega-3 Fatty acids could alleviate the risks of traumatic brain injury - a mini review. J Tradit Complement Med. 2014; 4:89-92.

18. Thomas J, Thomas CJ, Radcliffe J, Itsiopoulos C. Omega-3 fatty acids in early prevention of inflammatory neurodegenerative disease: a focus on Alzheimer's disease. Biomed Res Int. 2015; 2015:172801.

19. Pham-Huy LA, He H, Pham-Huy C. Free radicals, antioxidants in disease and health. Int $\mathrm{J}$ of Biomed Sci. 2008; 4:89-96.

20. van Goor SA, Dijck-Brouwer DA, Fokkema MR, van der Iest TH, Muskiet FA. Maternal and fetal brain contents of docosahexaenoic acid (DHA) and arachidonic acid (AA) at various essential fatty acid (EFA), DHA and AA dietary intakes during pregnancy in mice. Prostaglandins Leukot Essent Fatty Acids. 2008; 78:159-169.

21. Adarme-Vega TC, Lim DK, Timmins M, Vernen F, Li Y, Schenk PM. Microalgal biofactories: a promising approach towards sustainable omega-3 fatty acid production. Microb Cell Fact. 2012; 11:96.

22. Werman MJ, Sukenik A, Mokady S. Effects of the marine unicellular alga Nannochloropsis sp. to reduce the plasma and liver cholesterol levels in male rats fed on diets with cholesterol. Biosci Biotechnol Biochem. 2003; 67:2266-2268.
23. Upadhyay AK, Singh NK, Singh R, Rai UN. Amelioration of arsenic toxicity in rice: comparative effect of inoculation of Chlorella vulgaris and Nannochloropsis sp. on growth, biochemical changes and arsenic uptake. Ecotoxicology Environ Saf. 2016; 124:68-73.

24. Ismail $\mathrm{N}$, Ismail $\mathrm{M}$, Azmi NH, Abu Bakar MF, Basri H, Abdullah MA. Modulation of hydrogen peroxide-induced oxidative stress in human neuronal cells by thymoquinonerich fraction and thymoquinone via transcriptomic regulation of antioxidant and apoptotic signaling genes. Oxid Med Cell Longev. 2016; 2016:2528935.

25. Pereira H, Custodio L, Rodrigues MJ, de Sousa CB, Oliveira M, Barreira L, Neng Nda R, Nogueira JM, Alrokayan SA, Mouffouk F, Abu-Salah KM, Ben-Hamadou $\mathrm{R}$, Varela J. Biological activities and chemical composition of methanolic extracts of selected autochthonous microalgae strains from the Red Sea. Mar Drugs. 2015; 13:3531-3549.

26. Sadigh-Eteghad S, Sabermarouf B, Majdi A, Talebi M, Farhoudi M, Mahmoudi J. Amyloid-beta: a crucial factor in Alzheimer's disease. Medi Princ Pract. 2015; 24:1-10.

27. Wang WY, Tan MS, Yu JT, Tan L. Role of pro-inflammatory cytokines released from microglia in Alzheimer's disease. Annal Trans Med. 2015; 3:136.

28. Rodriguez JJ, Butt AM, Gardenal E, Parpura V, Verkhratsky A. Complex and differential glial responses in Alzheimer's disease and ageing. Cur Alzheimer Res. 2016; 13:343-358.

29. Lee JC, Hou MF, Huang HW, Chang FR, Yeh CC, Tang JY, Chang HW. Marine algal natural products with antioxidative, anti-inflammatory, and anti-cancer properties. Cancer Cell Int. 2013; 13:55.

30. Lee JW, Lee YK, Yuk DY, Choi DY, Ban SB, Oh KW, Hong JT. Neuro-inflammation induced by lipopolysaccharide causes cognitive impairment through enhancement of betaamyloid generation. J Neuroinflammation. 2008; 5:37.

31. Qin L, Wu X, Block ML, Liu Y, Breese GR, Hong JS, Knapp DJ, Crews FT. Systemic LPS causes chronic neuroinflammation and progressive neurodegeneration. Glia. 2007; 55:453-462.

32. Lin GH, Lee YJ, Choi DY, Han SB, Jung JK, Hwang BY, Moon DC, Kim Y, Lee MK, Oh KW, Jeong HS, Leem JY, Shin HK, et al. Anti-amyloidogenic effect of thiacremonone through anti-inflamation in vitro and in vivo models. J Alzheimer Dis. 2012; 29:659-676.

33. Morgan MJ, Liu ZG. Crosstalk of reactive oxygen species and NF-kappaB signaling. Cell Res. 2011; 21:103-115.

34. Kim DH, Chung JH, Yoon JS, Ha YM, Bae S, Lee EK, Jung KJ, Kim MS, Kim YJ, Kim MK, Chung HY. Ginsenoside $\mathrm{Rd}$ inhibits the expressions of iNOS and COX-2 by suppressing NF-kappaB in LPS-stimulated RAW264.7 cells and mouse liver. J Ginseng Res. 2013; 37:54-63.

35. Xiang Y, Meng S, Wang J, Li S, Liu J, Li H, Li T, Song W, Zhou W. Two novel DNA motifs are essential for BACE1 gene transcription. Sci Rep. 2014; 4:6864. 
36. Kaur U, Banerjee P, Bir A, Sinha M, Biswas A, Chakrabarti S. Reactive oxygen species, redox signaling and neuroinflammation in Alzheimer's disease: the NF-kappaB connection. Curr Top Med Chem. 2015; 15:446-457.

37. Lv H, Yu Z, Zheng Y, Wang L, Qin X, Cheng G, Ci X. Isovitexin exerts anti-inflammatory and anti-oxidant activities on lipopolysaccharide-induced acute lung injury by inhibiting MAPK and NF-kappaB and activating HO-1/ Nrf2 pathways. Int J Biol Sci. 2016; 12:72-86.

38. Ben Haim L, Ceyzeriat K, Carrillo-de Sauvage MA, Aubry F, Auregan G, Guillermier M, Ruiz M, Petit F, Houitte D, Faivre E, Vandesquille M, Aron-Badin R, Dhenain M, et al. The JAK/STAT3 pathway is a common inducer of astrocyte reactivity in Alzheimer's and Huntington's diseases. J Neurosci. 2015; 35:2817-2829.

39. Zhang Q, Deng Y, Lai W, Guan X, Sun X, Han Q, Wang F, Pan X, Ji Y, Luo H, Huang P, Tang Y, Gu L, et al. Maternal inflammation activated ROS-p38 MAPK predisposes offspring to heart damages caused by isoproterenol via augmenting ROS generation. Sci Rep. 2016; 6:30146.

40. Hartono SP, Knudsen BE, Zubair AS, Nath KA, Textor SJ, Lerman LO, Grande JP. Redox signaling is an early event in the pathogenesis of renovascular hypertension. Int $\mathrm{J}$ Mol Sci. 2013; 14:18640-18656.

41. Nita M, Grzybowski A. The role of the reactive oxygen species and oxidative stress in the pathomechanism of the age-related ocular diseases and other pathologies of the anterior and posterior eye segments in adults. Oxid Med Cell Longev. 2016; 2016:3164734.

42. Swomley AM, Forster S, Keeney JT, Triplett J, Zhang Z, Sultana R, Butterfield DA. Abeta, oxidative stress in Alzheimer disease: evidence based on proteomics studies. Biochim Biophys Acta. 2014; 1842:1248-1257.

43. Limongi D, Baldelli S. Redox imbalance and viral infections in neurodegenerative diseases. Oxid Med Cell Longev. 2016; 2016:6547248.

44. von Bernhardi R, Eugenin-von Bernhardi L, Eugenin J. Microglial cell dysregulation in brain aging and neurodegeneration. Front Aging Neurosci. 2015; 7:124.

45. Wang S, Liu C, Pan S, Miao Q, Xue J, Xun J, Zhang Y, Gao Y, Duan X, Fan Y. Deferoxamine attenuates lipopolysaccharide-induced inflammatory responses and protects against endotoxic shock in mice. Biochem Biophys Res Commun. 2015; 465:305-311.

46. Deng X, Li M, Ai W, He L, Lu D, Patrylo PR, Cai H, Luo X, Li Z, Yan X. Lipolysaccharide-induced neuroinflammation is associated with alzheimer-like amyloidogenic axonal pathology and dendritic degeneration in rats. Adv Alzheimer Dis. 2014; 3:78-93.

47. Cai Y, Zhang XM, Macklin LN, Cai H, Luo XG, Oddo S, Laferla FM, Struble RG, Rose GM, Patrylo PR, Yan $\mathrm{XX}$. BACE1 elevation is involved in amyloid plaque development in the triple transgenic model of Alzheimer's disease: differential Abeta antibody labeling of early-onset axon terminal pathology. Neurotox Res. 2012; 21:160-174.

48. Lee YJ, Han SB, Nam SY, Oh KW, Hong JT. Inflammation and Alzheimer's disease. Arch Pharm Res. 2010; 33:1539-1556.

49. Zuo L, Hemmelgarn BT, Chuang CC, Best TM. The role of oxidative stress-induced epigenetic alterations in amyloidbeta production in Alzheimer's disease. Oxid Med Cell Longev. 2015; 2015:604658.

50. Mao P, Manczak M, Calkins MJ, Truong Q, Reddy TP, Reddy AP, Shirendeb U, Lo HH, Rabinovitch PS, Reddy PH. Mitochondria-targeted catalase reduces abnormal APP processing, amyloid beta production and BACE1 in a mouse model of Alzheimer's disease: implications for neuroprotection and lifespan extension. Hum Mol Genet. 2012; 21:2973-2990.

51. Lee YK, Yuk DY, Lee JW, Lee SY, Ha TY, Oh KW, Yun YP, Hong JT. (-)-Epigallocatechin-3-gallate prevents lipopolysaccharide-induced elevation of beta-amyloid generation and memory deficiency. Brain Res. 2009; 1250:164-174.

52. Kim TI, Lee YK, Park SG, Choi IS, Ban JO, Park HK, Nam SY, Yun YW, Han SB, Oh KW, Hong JT. 1-Theanine, an amino acid in green tea, attenuates beta-amyloid-induced cognitive dysfunction and neurotoxicity: reduction in oxidative damage and inactivation of ERK/p38 kinase and NF-kappaB pathways. Free Rad Biol Med. 2009; 47:1601-1610.

53. Chauhan V, Chauhan A. Oxidative stress in Alzheimer's disease. Pathophysiology. 2006; 13:195-208.

54. Tak PP, Firestein GS. NF-kappaB: a key role in inflammatory diseases. J Clinical Invest. 2001; 107:7-11.

55. Erickson MA, Banks WA. Cytokine and chemokine responses in serum and brain after single and repeated injections of lipopolysaccharide: multiplex quantification with path analysis. Brain Behav Immun. 2011; 25:1637-1648.

56. Sung S, Yang H, Uryu K, Lee EB, Zhao L, Shineman D, Trojanowski JQ, Lee VM, Pratico D. Modulation of nuclear factor-kappa B activity by indomethacin influences A beta levels but not A beta precursor protein metabolism in a model of Alzheimer's disease. Am J Pathol. 2004; 165:2197-2206.

57. Echeverria V, Burgess S, Gamble-George J, Zeitlin R, Lin X, Cao C, Arendash GW. Sorafenib inhibits nuclear factor kappa B, decreases inducible nitric oxide synthase and cyclooxygenase- 2 expression, and restores working memory in APPswe mice. Neuroscience. 2009; 162:1220-1231.

58. Shi JQ, Zhang CC, Sun XL, Cheng XX, Wang JB, Zhang YD, Xu J, Zou HQ. Antimalarial drug artemisinin extenuates amyloidogenesis and neuroinflammation in APPswe/PS1dE9 transgenic mice via inhibition of nuclear 
factor-kappaB and NLRP3 inflammasome activation. CNS Neurosci Ther. 2013; 19:262-268.

59. Lee YJ, Choi IS, Park MH, Lee YM, Song JK, Kim YH, Kim KH, Hwang DY, Jeong JH, Yun YP, Oh KW, Jung JK, Han SB, Hong JT. 4-O-Methylhonokiol attenuates memory impairment in presenilin 2 mutant mice through reduction of oxidative damage and inactivation of astrocytes and the ERK pathway. Free Rad Biol Med. 2011; 50:66-77.

60. Lee JW, Lee YK, Ban JO, Ha TY, Yun YP, Han SB, Oh KW, Hong JT. Green tea (-)-epigallocatechin-3-gallate inhibits beta-amyloid-induced cognitive dysfunction through modification of secretase activity via inhibition of ERK and NF-kappaB pathways in mice. J Nutr. 2009; 139:1987-1993.

61. Schubert D, Soucek T, Blouw B. The induction of HIF-1 reduces astrocyte activation by amyloid beta peptide. European J Neurosci. 2009; 29:1323-1334.

62. Vassar R. BACE1 inhibitor drugs in clinical trials for Alzheimer's disease. Alzheimer Res Ther. 2014; 6:89.

63. Morris R. Developments of a water-maze procedure for studying spatial learning in the rat. J Neurosci Methods. 1984; 11:47-60.

64. Lee YJ, Choi DY, Choi IS, Kim KH, Kim YH, Kim HM, Lee K, Cho WG, Jung JK, Han SB, Han JY, Nam SY, Yun YW, et al. Inhibitory effect of 4-O-methylhonokiol on lipopolysaccharide-induced neuroinflammation, amyloidogenesis and memory impairment via inhibition of nuclear factor-kappaB in vitro and in vivo models. J Neuroinflammation. 2012; 9:35.

65. Jang H, Lee JW, Lee C, Jin Q, Choi JY, Lee D, Han SB, Kim Y, Hong JT, Lee MK, Hwang BY. Sesquiterpenoids from Tussilago farfara inhibit LPS-induced nitric oxide production in macrophage RAW 264.7 cells. Arch Pharm Res. 2016; 39:127-132.

66. Hwang CJ, Yun HM, Park KR, Song JK, Seo HO, Hyun BK, Choi DY, Yoo HS, Oh KW, Hwang DY, Han SB, Hong JT. Memory Impairment in Estrogen Receptor $\alpha$ Knockout Mice Through Accumulation of Amyloid- $\beta$ Peptides. Mol Neurobiol. 2015; 52:176-86.

67. Hartlage-Rubsamen M, Zeitschel U, Apelt J, Gartner U, Franke H, Stahl T, Gunther A, Schliebs R, Penkowa M, Bigl V, Rossner S. Astrocytic expression of the Alzheimer's disease beta-secretase (BACE1) is stimulus-dependent. Glia. 2003; 41:169-179.

68. Ghareeb DA, Khalil S, Hafez HS, Bajorath J, Ahmed HE, Sarhan E, Elwakeel E, El-Demellawy MA. Berberine reduces neurotoxicity related to nonalcoholic steatohepatitis in rats. Evid Based complement Alternat Med. 2015; 2015:361847.

69. Gu SM, Park MH, Hwang CJ, Song HS, Lee US, Han SB, Oh KW, Ham YW, Song MJ, Son DJ, Hong JT. Bee venom ameliorates lipopolysaccharide-induced memory loss by preventing NF-kappaB pathway. J Neuroinflammation. $2015 ; 12: 124$. 